DOI: 10.26907/2311-2042-2021-17-2-190-195

\title{
PROMINENT LINGUIST HISAMOVA FAGIMA
}

\author{
Alfiya Shavketovna Yusupova, \\ Kazan Federal University, \\ 18 Kremlyovskaya Str., Kazan, 420008, Russian Federation, \\ alyusupova@yandex.ru.
}

Gulnaz Foatovna Gainullina, Commission on the Preservation and Development of Tatar Language, 1 Svobody Square, Kazan, 420008, Russian Federation, ggf@inbox.ru.

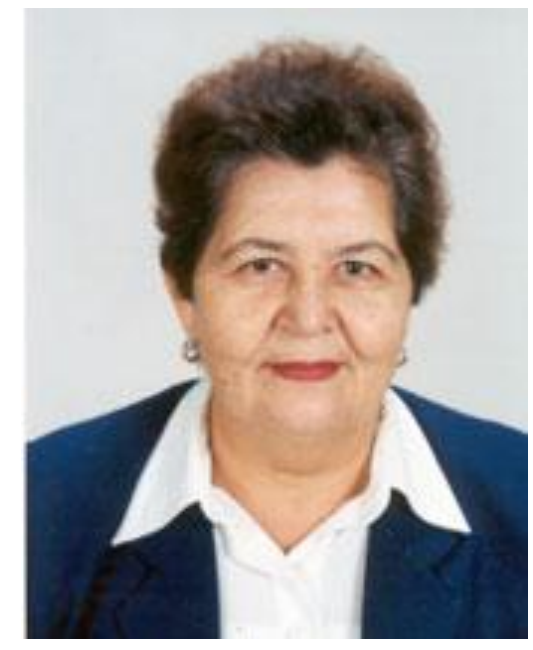

Khisamova Fagima Mirgalievna (1936-2018) was a linguist, Doctor of Philology (1995), professor (1998), member of the International Turkic Academy (1997), Honored Scientist of the Republic of Tatarstan, Honored Teacher of Tatarstan (1994), head of the Tatar language department in 1999-2004. She was the author of textbooks and teaching aids for educational organizations and a Labor Veteran (1986).

She devoted her research works to the history of the Tatar literary language, historical grammar, morphology of the modern Tatar language, history and spelling of the Tatar language, language and textology of Turkic written monuments.
Хисамова Фәһимә Миргали кызы (1936 - 2018) - тел галиме, филология фәннәре докторы (1995), профессор (1998), Халыкара төрки академиянең хакыйкый әгъзасы (1997), Татарстан Республикасының атказанган фән эшлеклесе, Татарстанның атказанган укытучысы (1994), 1999 - 2004 елларда татар теле кафедрасы мөдире; гомуми белем бирү оешмалары өчен дәреслекләр һәм уку әсбаплары авторы. Хезмәт ветераны (1986).

Гыйльми хезмәтләре татар әдәби теле тарихы, тарихи грамматика, хәзерге татар теле морфологиясе, татарларда язу тарихы һәм орфография, төрки язма истәлекләр теле һәм текстологиясе мәсьәләләрен тикшерүгә багышланган.
Хисамова Фагима Миргалеевна (1936-2018) - языковед, доктор филологических наук (1995), профессор (1998), действительный член Международной Тюркской академии (1997), заслуженный деятель науки Республики Татарстан, заслуженный учитель Татарстана (1994), заведующая кафедрой татарского языка в 1999-2004 гг.; автор учебников и учебных пособий для общеобразовательных организаций. Ветеран труда (1986).

Научные труды посвящены вопросам истории татарского литературного языка, исторической грамматики, морфологии современного татарского языка, истории и орфографии татарского языка, языка и текстологии тюркских письменных памятников.
Fagima Khisamova (Nigmatullina) was born on December 1, 1936 in the village of Karakalino, the Yutazinsky district. She went to a primary school there. In the post-war years, Fagima Khisamova worked as a teacher at the Karakalinskaya secondary school, she was a dili- 
gent and conscientious teacher. In 1955-1960, she studied at the Department of Tatar Philology of Kazan State University. After graduating from the university, F. Khisamova worked as a teacher in schools in the Drozhzhanovskiy and Aznakayevskiy districts for seven years. During these years, she started a family with her groupmate Nurmukhamet Khisamov. They moved to Kazan where they both did their postgraduate studies. The future professor F. Khisamova completed her postgraduate course (1967-1970) under the guidance of Dilara Tumasheva, an outstanding Turkologist, the first doctor of science in Tatar philology, the first female dean of Kazan University and the first Tatar woman to achieve an academic title.

Fagima Khisamova was a prominent scientist who found her place in the Tatar language studies. In 1971, she completed her Ph.D. thesis on the topic "The participle in the modern Tatar literary language". The results of this research occupy a special place in the academic editions of "Tatar Grammar", published in the Tatar and Russian languages $(1992,2002,2016)$. In 1995, F. Khisamova completed her doctoral dissertation on the topic "Features of the formation and use of the old Tatar official papers' style in the $16^{\text {th }}$-early $19^{\text {th }}$ centuries". The work was highly appreciated by the scientific community.

The history of the language is one of the most complicated and important fields of language, which requires wide knowledge in different spheres. Research into this field means, first of all, considerable work with archival materials, written monuments, sources written in various scripts. Of particular interest in this respect is F. Khisamova's monograph "The Tatar Language in Eastern Diplomacy of Russia (the $16^{\text {th }}$-early $19^{\text {th }}$ centuries)" (2012). As a result of her research on manuscripts and letters in Arabic script, stored in numerous archives, F. Khisamova became one of the first scholars to come to the conclusion that the Tatar language, as a diplomatic language in the Russian state, was in use for two or three centuries [1], and that in the Middle Volga and Ural regions, the Tatar language was the language of communication for different nationalities, also, the diplomatic relations of the Russian state with the Caucasus and the Middle East, Central Asia, and the countries of East Asia were conducted in the Tatar language. Noting the importance of the monograph, E. A. Grunina said: "The work's significance is not limited to the history of the Tatar literary language. This research is relevant in the studies of other Turkic languages that have a rich written tradition" [2].
In her interview to journalists in 2011, Fagima Khisamova said: "Our purpose is to study historical grammars and the changes our language has undergone from antiquity to the present day" [3]. It must be said that the scientist made a significant contribution to this scientific trend. In 2017, the book "Historical Grammar of the Tatar Language. Phonetics. Morphology" was published. It is important to note that this was the first fundamental work, reflecting the evolution of the Tatar sounds, parts of speech and grammatical categories in one monograph. In the first part of the monograph, the author, along with the issues of vocalism, consonantism, stress and sound changes in the Tatar language, clarifies the controversial aspects of a complex phenomenon called the transition of vowels in Turkic languages of the Volga region (chronological boundaries, the presence of regional specifics, reasons, attitudes to the substrate theory, etc.). The section 'Morphonology' analyzes syllables, suffixes and their origin in the Tatar language on a scientific basis. In the section "Historical Morphology", the study of individual languages, belonging to the family of Turkic languages, primarily Tatar grammatical categories, is studied in relation to the reconstructed Turkic language, as well as reconstructed basic languages of various regional Turkic languages.

Despite the fact that the monograph is called "Historical Grammar of the Tatar Language", the work provides rich scientific information about the facts concerning the historical grammar of many other Turkic languages (Turkish, Chuvash, Yakut, Tuvan, Kyrgyz, Khakass, Altai, etc.), the language of the Turkic written monuments dating back to different periods; thus, the study of the evolution of the Tatar historical grammar is carried out in a comparative-historical way. In the work, the sources are presented both in the Latin script, adopted by the International Phonetic Association, and in the Cyrillic alphabet, which, in our opinion, is justified.

One of the branches of F. Khisamova's research is modern morphology of the Tatar language. In 2006, as a result of numerous studies, her textbook "Morphology of the Tatar Language" appeared. Academician M. Zakiev wrote about this work: "This will be the first textbook that reveals the morphological system of the Tatar language in a logical sequence" [4]. The work provides detailed scientific information about morphology, the object of its study being morphemics, word formation, parts of speech and their grammatical categories. The textbook carefully analyzes each 
grammatical phenomenon, provides a variety of controversial views associated with a particular concept, which the author discusses expressing her own opinion. The work gives examples of questions and samples of morphological analysis to test knowledge. Thus, this work demonstrates the development of Fagima Khisamova's scientific and pedagogical experience. In 2015, the textbook was reissued.

F. Khisamova conducted scientific research in the area of the Tatar alphabet and spelling. Having scientifically substantiated the need for the Latin alphabet, she published the popular scientific work "The Tatar Language: Scientific Foundations of the Return to the Latin Alphabet" (2004) in Tatar and Russian.

Fagima Khisamova's career was associated with Kazan State University: first as an assistant, then as a senior teacher, an associate professor, from 1998 - a professor. From 1999 to 2004, Fagima Khisamova headed the department of the Tatar language. At the university, she lectured on Tatar morphology, history of the language, historical grammar, phonetics, held practical classes on the old Tatar language, textual studies of written monuments and linguistic features and had special courses with university students. Each of her lessons was a discovery of new knowledge. As a lecturer, she could be logical and consistent explaining complex and controversial theoretical materials, illustrating them with specific examples. These qualities of hers are reflected in her works.

The scientific and pedagogical activities of the scholar were connected with the development of various programs, university textbooks and teaching aids. F. Khisamova was the author of the works "Collection of Exercises on Tatar Morphology" (1973), "Modern Tatar Language. Morphology (a textbook for university students)" (1981) and "Phonetics of the Modern Tatar Language" (1981), she was also the editor of many educational programs.

Fagima Khisamova's methodological books for preschoolers and schoolchildren, educators and teachers found a worthy place among the scientific and pedagogical works. Her work "Children Study the Tatar Language. A Methodological Manual for Preschool Teachers" (co-author R. A. Burganova) $(1994 ; 2005)$ has been a handbook for educators to this day.

F. Khisamova took part in the compilation of textbooks on the native language for educational organizations. The textbooks for Tatar children, studying in Russian schools, have been republished in co-authorship with F. Kharisov and Ch. Kharisova. In addition, the journal "Kazan utlary" ("Lights of Kazan") published a series of her articles "Lessons of the Tatar Language" in 19891990, which found their regular readers.

Numerous $\mathrm{Ph}$. D. theses were completed under the scientific supervision of F. Khisamova. Currently, in various educational and research institutions, her students R. Yuzlukhametov (2002), G. Garipova (2003), R. Khurmatullina (2004), F. Mukhametshin (2007), V. Fakhrutdinova (2007), L. Sadykova (2010), M. Sakhunov (2010), L. Khisamova (2010) are doing research making a worthy contribution to the issues of the Tatar language studies.

Fagima Khisamova was a well-educated, cultured and deeply thinking person. The name and heritage of the scientist, who devoted herself to the study, development and preservation of the language, to education of students, occupies an honorable place not only in the history of the Tatar language, but also in the history of general Turkology.

\section{References}

Grunina, E. A. (2017). Tsennyi vklad v izuchenie istorii tyurkskikh iazykov (retsenziia na knigu Khisamova F. M. Tatarskii iazyk $v$ vostochnoi diplomatii Rossii (XVI - nachalo XIX vv.) 401 p. Kazan: Master-Lain, 1999) [A Valuable Contribution to the Study of the History of Turkic Languages (review of F. M. Khisamova's book "The Tatar Language in Eastern Diplomacy of Russia". 401 p. Kazan: Master-Lain, 1999)]. Fəngə bagyshlangan gomer: Nurmekhəmmət həm Fəhimə Khisamovlarnyң 80 iash'legenə. Tөzүche həm жavaply mekhərrir E. I. Safina. 176 p. Kazan', ILLaA. (In Tatar)

Fagima Khisamova: "Khazer telne oiranyda funltsional'-tematik iunaleshka kYchy bik ahamiiatle [Fogimo Khisamova: "Now the transition to a functional-thematic focus in language learning is very significant"]. URL: http://tatar-inform.tatar/news/tatarstan/ 2011/10/20/70212/ (accessed: 11.10. 2016). (In Tatar)

Khisamova, F. M. (2012). Tatarskii iazyk v vostochnoi diplomatii Rossii (XVI - nachalo XIX vv.) [The Tatar Language in Eastern Diplomacy of Russia (the $16^{\text {th }}-$ early $19^{\text {th }}$ centuries)]. 399 p. Kazan', Tatar.kit.nəshr. (In Tatar)

Zakiev, M. Z. (2006). Kafedranym bishenche modire [The Fifth Head of the Department]. I gaziz tugan telem! 235 p. Kazan', KSU kit.nəshr. (In Tatar) 


\title{
ТЕЛ ГАЛИМЕ ХИСАМОВА ФӘһИМӘ МИРГАЛИЕВНА
}

\author{
Әлфия Шәүкәт кызы Юсупова, \\ Казан федераль университеты, \\ Россия, 420008, Казан ш., Кремль ур., 18 нче йорт, \\ alyusupova@yandex.ru.
}

Гөлназ Фоат кызы Гайнуллина, Татарстан Республикасы Президенты каршындагы Татар телен саклау һәм үстерү мәсьәләләре комиссиясе, Россия, 420060, Казан ш., Ирек мәйданы, 1 нче йорт, ggf@inbox.ru.

Фәһимә Хисамова (Нигъмәтуллина) 1936 елның 1 декабрендә Ютазы районының Кәрәкәшле авылында дөньяга килә. Башлангыч белемне туган авылы мәктәбендә ала. Сугыштан соңгы елларда Фәһимә Миргалиевна Кәрәкәшле мәктәбендә укытучы булып эшли, тырыш, намуслы мөгаллимә булып таныла. 1955-1960 елларда Казан дәүләт университетының татар филологиясе бүлегендә укый. Университетны тәмамлаганнан соң, Ф. Хисамова жиде ел дәвамында Чүпрәле һәм Азнакай районы мәктәпләрендә укытучы булып эшли. Шушы елларда ул үзенең курсташы Нурмөхәммәт Хисамов белән гаилә кора. Алар янәдән Казанга күчеп, икесе дә аспирантурага укырга керәләр. Булачак профессор Ф. Хисамова аспирантураны татар филологиясендә беренче фән докторы, Казан университетында беренче хатын-кыз деканы, татар хатын-кызларыннан иң беренче булып академик дәрәжәсенә ирешкән күренекле тюрколог Диләрә Гариф кызы Тумашева житәкчелегендә уза (1967-1970).

Фәһимә Миргалиевна Хисамова - беренче чиратта, татар тел белеме фәнендә үз урынын тапкан күренекле галим. Ул 1971 елда «Хәзерге татар әдәби телендә сыйфат фигыльләр» («Причастие в современном татарском литературном языке») дигән темага кандидатлык диссертациясе яклый. Әлеге тикшеренү нәтижәләре татар һәм рус телләрендә дөнья күргән "Татар грамматикасы” дип аталган академик басмаларда аерым бүлек буларак урын ала (1992, 2002, 2016). 1995 елда Ф. Хисамова «Иске татар рәсми эш кәгазьләре стиленең формалашуы һәм кулланылыш үзенчәлекләре (XVI йөз - XIX йөзнең беренче яртысы)» («Функционирование и развитие старотатарской деловой письменности XVI - I половины XIX вв.») дигән темага язылган докторлык диссертациясен яклый. Хезмәт фәнни жәмәгатьчелек тарафыннан югары бәяләнә.
Тел тарихы - тел гыйлемендә катлаулы, жаваплы, тикшеренүчедән һәр өлкәдә мәгълүматлы һәм тирән белемле булуны таләп итә торган юнәлешләрнең берсе. Бу тармакта фәнни эзләнүләр алып бару иң элек архив материаллары, язма истәлекләр, төрле графикада язылган чыганаклар белән эш итүне күз алдында тота. Бу нисбәттән Ф. Хисамованың «Татарский язык в восточной дипломатии России (XVI - начало XIX вв.)» (2012) дип аталган монографиясе игътибарга лаек. Күпсанлы архивларда гарәп графикасындагы ярлык, кулъязма, хатларны табып, укып, аларның күчермәләрен алып тикшеренүләр үткәрү нәтижәсендә Ф. Хисамова беренчеләрдән булып татар теле рус дәүләтендә дипломатия теле буларак, ике-өч гасыр кулланылышта була дигән нәтижәгә килә [Хисамова, 399 б.], Урта Идел һәм Урал төбәкләрендә төрле милләттәге халыклар өчен татар теленең аралашу теле булуын, Россия дәүләтенең Кавказ һәм Якын Көнчыгыш, Урта Азия, Көнчыгыш Азия илләре белән дипломатик мөнәсәбәтләрнең татар телендә алып барылуын халыкка житкерә. Монографиянең нәзари әһәмиятен билгеләп, Э.А. Грунина болай ди: “Хезмәтнең әһәмияте татар әдәби теле тарихы мәсьәләләре белән генә чикләнми, ул әлеге проблеманың бай язма традициягә ия булган башка төрки телләр материалында өйрәнелүе жәһәтеннән дә актуаль" [Грунина, 401 б.].

2011 елда журналистларга биргән бер интервьюсында Фәһимә Хисамова: "Безнең бурыч - телебез бик борынгыдан алып бүгенге көнгә кадәр нинди үзгәрешләр кичергәнлеген барлап, тарихи грамматиканы эшләү" - дигән иде. [Фәнгә..., 176 б.]. Әйтергә кирәк, галимә бу юнәлештә дә үзеннән саллы өлеш кертте. 2017 елда "Татар теленең тарихи грамматикасы. Фонетика. Морфология" дип аталган саллы китабы дөнья күрде. Шуны искәртү мөһим: бу 
хезмәт - татар теленең авазлар системасының, сүз төркемнәре һәм грамматик категорияләренең эволюциясен бер монографиядә чагылдырган беренче фундаменталь хезмәт. Монографиянең беренче бүлегендә автор, татар телендәге вокализм, консонантизм, басым, аваз үзгәрешләре мәсьәләләре белән беррәттән, классик тюркология фәнендә Идел буендагы төрки телләрдә сузыклар күчеше дип аталган катлаулы күренешнең бәхәсле якларына да (хронологик чикләре, региональ үзенчәлек булу-булмавы, табигате, сәбәпләре, субстрат теориясенә мөнәсәбәте һ.б.) ачыклык кертә. “Морфонология" бүлегендә татар телендәге ижек калыплары, кушымчалар һәм аларның килеп чыгышы фәнни нигездә анализлана. “Тарихи морфология" бүлегендә исә төрки телләр семьялыгына кергән аерым телләрнең, беренче чиратта, татар теленең, грамматик категорияләрен өйрәнү реконструкцияләнгән борынгы төрки нигез телгә, шулай ук төрле региональ төрки телләрнең реконструкцияләнгән нигез телләренә мөнәсәбәттә өйрәнелә.

Монография "Татар теленең тарихи грамматикасы” дип аталса да, хезмәт башка бик күп төрки телләрнең (төрек, чуваш, якут, тува, кыргыз, хакас, алтай h.б.) тарихи грамматикаларына, төрле чорга караган төрки язма истәлекләре теленә нисбәтле фактлар турында да бай фәнни мәгълүмат бирә, шул рәвешле татар теле тарихи грамматикасының эволюциясен тикшеру чагыштырма-тарихи ысул ярдәмендә тормышка ашырыла. Хезмәттә чыганак материалларын латин графикасына нигезләнгән Халыкара фонетик ассоциация кабул иткән язуда һәм кириллицада бирү, безнең фикеребезчә, үзен аклый.

Ф.М. Хисамованың фәнни тикшеренү өлкәләренең берсе - хәзерге татар теле морфологиясе. 2006 елда аның күп еллык эзләнүләренең нәтижәсе буларак, “Татар теле морфологиясе” дәреслеге дөнья күрде. Әлеге хезмәт турында академик М.З.Зәкиев болай дип яза: “Бу татар теленең морфологик системасын логик эзлеклелектә ачып бирә торган беренче дәреслек булачак" [Зәкиев, 235 б.]. Хезмәттә морфология, аның өйрәнү объекты, морфемика, сүз ясалышы, сүз төркемнәре һәм аларның грамматик категорияләре турында фәнни яктан төгәл мәгълүмат бирелә. Дәреслектә һәр грамматик күренеш жентекле анализлана, теге яки бу төшенчә белән бәйле бәхәсле фикерләр, карашлар төрлелеге китерелә, автор аларга Ү3 мөнәсәбәтен житкерә. Хезмәттә белемнәрне тикшеру өчен сораулар һәм морфологик анализ үрнәкләре дә бирелә. Шул рәвешле, биредә Фәһимә Миргали кызының фәнни һәм педагогик тәжрибәсе кушылып, югары дәрәжәдә эшләнгән хезмәт барлыкка килә. 2015 елда дәреслек яңадан бастырыла.

Ф. Хисамова татар теленең графикасы һәм орфографиясе юнәлешендә дә фәнни тикшеренүләр алып бара. Латин графикасының зарурлыгын беренчеләрдән булып фәнни дәлилләп, “Татар теле: латин әлифбасына кайтуның фәнни нигезләре" (2004) фәнни-популяр хезмәтен татар һәм рус телләрендә бастырып чыгара.

Фәһимә Миргали кызы Хисамованың хезмәт юлы Казан дәүләт университеты белән бәйле: башта ассистент, аннан өлкән укытучы, доцент, 1998 елдан профессор вазифаларын башкара. 1999 елдан 2004 елга кадәр Фәһимә Миргали кызы татар теле кафедрасы белән житәкчелек итә. Университетта ул татар теле морфологиясе, тел тарихы, тарихи грамматика, фонетика буенча лекцияләр укый, иске татар теле, язма истәлекләрнең текстологиясе һәм тел үзенчәлекләре буенча гамәли дәресләр, махсус курслар алып бара. Аның һәр дәресе - үзе бер ачыш. Лектор буларак, катлаулы, бәхәсле, теоретик материалларны да үтемле, логик эзлекле итеп житкерә, конкрет мисаллар белән дәлилли. Бу сыйфаты аның хезмәтләрендә дә чагылыш таба.

Галимәнең фәнни-педагогик эшчәнлеге төрле программалар, вуз дәреслекләре, методик кулланмалары төзу белән үрелеп бара. Ф. М. Хисамова - “Татар теле морфологиясеннән күнегүләр жыентыгы” (1973), “Хәзерге татар теле. Морфология (студентлар өчен методик әсбап)" (1981), “Хәзерге татар теле фонетикасы. Студентлар өчен лекцияләр һәм методик күрсәтмәләр" (1981) авторы, күп сандагы программаларның редакторы да була.

Фәһимә Миргалиевнаның мәктәпкәчә яшьтәге һәм мәктәп укучылары, тәрбиячеләре, укытучылары өчен төзелгән методик хезмәтләре дә фәнни-педагогик жәмәгатьчелектә лаеклы урынын тапты. "Татар теле өйрәнә нәниләр. Балалар бакчалары тәрбиячеләренә кулланма"сы (автордашы Р.А.Борһанова) (1994; 2005) тәрбиячеләр өчен әле дә өстәл китабы ролен үти.

Ф.М. Хисамова гомуми белем бирү оешмалары өчен туган тел дәреслекләре төзүдә дә катнаша. Рус мәктәпләрендә укучы татар балалары өчен дәреслекләре Ф.Ф. Харисов, Ч.М. Харисовлар белән авторлыкта берничә 
тапкыр басылып чыга. Моннан тыш, “Казан утлары” журналында 1989-1990 елларда аның “Татар теле дәресләре” дигән мәкаләләр циклы дөнья күрә һәм даими укучысын таба.

Ф.М. Хисамова житәкчелегендә күпсанлы кандидатлык диссертацияләре якланды. Хәзерге вакытта төрле уку йортларында, фәннитикшеренү учреждениеләрендә хезмәт куючы шәкертләре Р.Т. Йөзмөхәммәтов (2002), Г.Ф. Гарипова (2003), Р.Ш. Хөрмәтуллина (2004), Ф.М. Мөхәммәтшин (2007), В.Р. Фәхретдинова (2007), Л.Р. Садыйкова (2010), М.Р. Сәйхунов (2010), Л.А. Хисамовалар (2010) татар теле һәм, гомумән, төрки тел белеменең төрле мәсьәләләрен өйрәнүгә лаеклы өлеш кертәләр.

Фәһимә Миргалиевна Хисамова - киң эрудицияле, культуралы һәм тирән фикерле шәхес. Көч-егәрен телне өйрәнүгә, үстерү һәм саклауга, фәнгә, студентларга белем бирүгә багышлаган галимнең исеме һәм мирасы татар теле белеме тарихында гына түгел, гомум- тюркология фәне тарихында да хаклы рәвештә мактаулы урын алды.

\section{Әдәбият}

Хисамова Ф.М. Татарский язык в восточной дипломатии России (XVI - начало XIX вв.) - Казань: Тат. кн. изд-во, 2012. - 399 с.

Грунина Э.А. Ценный вклад в изучение истории тюркских языков (рецензия на книгу. Хисамова Ф.М. Татарский язык в восточной дипломатии России). Казань: Изд-во Мастер-Лайн, 1999. - 401 с.

Фәнгә багышланган гомер: Нурмөхәммәт һәм Фәһимә Хисамовларның 80 яшьлегенə / Төзүче һәм жаваплы мөхәррир Э.И.Сафина. Казан: ТӘһСИ, 2017. 176 б.

Фәһимә Хисамова: “Хәзер телне өйрәнүдә функциональ-тематик юнәлешкә күчү бик әһәмиятле // URL: http:/tatar-inform.tatar/news/ tatarstan/2011/10/20/70212/ (мөрәжәгать итү вакыты: 11.10.2016)

Зәкиев М.3. Кафедраның бишенче мөдире // И газиз туган телем! Казан: КДУ нәшр., 2006. - 2356. 